\title{
ARIMA Modeli ile Türkiye Fındık Üretim Projeksiyonu
}

\author{
Türkay BARS ${ }^{1}$ (D) Ilkay UÇUM 1 (D) Cuma AKBAY2 D \\ ${ }^{1}$ GTHB, Tarımsal Ekonomi ve Politika Geliştirme Enstitüsü Müdürlüğü Ankara, ${ }^{2}$ Kahramanmaraş Sütçü İmam Üniversitesi, Ziraat \\ Fakültesi, Tarım Ekonomisi Bölümü, Kahramanmaraş
}

$\bowtie$ : t.bars@hotmail.com

\begin{abstract}
ÖZET
Fındık, badem ve cevizden sonra dünyada üretimi en yaygın yapılan sert kabuklu meyvedir. Türkiye fındık üretiminde ve ihracatında dünyada ilk sıradadır. Bu nedenle uluslararası findık piyasanın şekillenmesinde önemli rol oynamaktadır. Türkiye'de en fazla Karadeniz Bölgesinde yetiştirilen findık, gıda sanayiinde birçok ürünün içeriğinde kullanılmasından dolayı katma değeri yüksek olan bir üründür. Bu çalışmanın amacı, Türkiye'de fındık üretiminde mevcut durumun incelenmesi ve geleceğe yönelik beş ylllık üretim tahminlerinin yapılmasıdır. Zaman serilerinin elde edilmesinde, TÜIKK fındık üretim istatistiklerinden faydalanılmıştır. Fındık üretim miktarının tahmin edilmesinde ARIMA modeli kullanılmıştır. ARIMA yöntemi kullanılarak yapılan analizde en uygun modelin ARIMA (1,2,2) olduğu tespit edilmiştir. Analiz sonuçlarına göre, Türkiye findık üretiminin 2018 yılında yaklaşık 639 bin ton, 2022 yılında ise yaklaşık 648 bin ton olacağı tahmin edilmiştir.
\end{abstract}

\section{Turkey Hazelnut Production Projection with ARIMA Model}
ABSTRACT
Hazelnut is the most common hard-shelled fruit produced in the world, after almonds and walnuts. Turkey is in the first place in the world in hazelnut production and export. Therefore, it plays an important role in shaping the international hazelnut markets. Hazelnut, which is mostly grown in the Black Sea Region in Turkey, is a high value-added product due to the use of content of many products in food industry. The objective of this study was to examine the current situation in the hazelnut production in Turkey and make five-year production forecast for the future. In order to obtain time series, the hazelnut production statistics of Turkish Statistical Institute (TUIK) were used. The ARIMA model was used to estimate the amount of hazelnut production. ARIMA $(1,2,2)$ was found to be the most suitable model in the analysis by ARIMA method. According to the results of analysis, Turkey's hazelnut production in 2018 is approximately 639 thousand tons, while it is estimated to be approximately 648 thousand tons in 2022 .

Makale Tarihçesi

Geliş : 21.10.2018

Kabul : 26.12.2018

Anahtar Kelimeler

Findık Üretimi,

ARIMA,

Projeksiyon

\section{Araștırma Makalesi}

\section{Article History}

Received : 21.10.2018

Accepted : 26.12.2018

\section{Keywords \\ Hazelnut Production, \\ ARIMA, \\ Projection}

\section{Research Article}

To cite: Bars T, Uçum İ, Akbay C 2018. ARIMA Modeli ile Türkiye Fındık Üretim Projeksiyonu. KSÜ Tar Doğa Derg 21(Özel Sayı) : 154-160, DOI : 10.18016/ksutarimdoga.v21i41625.473029

\section{GİRIŞ}

İnsan sağlığı ve beslenmesinde çok önemli bir yere sahip olan findık, kolesterolü azaltma özelliğinin yanında, \%64 bitkisel yă̆, \%16,5 protein, \%14 karbonhidrat, zengin mineralleri (fosfor, demir ve kalsiyum) ve vitaminleri (A, B1, B2, B6, C ve E) içermektedir (Anıl ve ark. 2018). Yapılan bilimsel çalışmalara göre 100 gr. fındık, insanın günlük protein ihtiyacının \%22'sini karşılarken, 634 kaloride enerji vermektedir (ZMO, 2016).
Fındık, dünyada en yaygın olarak yetiştiriciliği yapılan sert kabuklu meyvelerin başında gelmektedir. Fındığın kültür çeşitleri Türkiye, İtalya, Azerbaycan, Gürcistan, İspanya, ABD, Çin, İran, Yunanistan, Fransa, Rusya, Portekiz, Beyaz Rusya, Moldova, Macaristan, Kırgizistan, Tacikistan, Ukrayna, Tunus, Kıbrıs ve Kamerun olmak üzere birçok ülkede yetiştirilmektedir (Özkan, 2012).

Dünyada üretilen findığın \%80'i çikolata sanayinde dilinmiş, kıyılmış, öğütülmüş olarak, \%10-12'si 
pastacılık-bisküvi-unlu mamuller sektörlerinde kullanılırken, \%3-4'ü çerez olarak, kalanı ise dondurma sektöründe ve yağ sanayinde değerlendirilmektedir (TMO, 2016). Türkiye'de ise üretilen findığıı \%70'i çikolata endüstrisinde, \%20'si pasta ve şekerleme için, yalnızca \%10 ise işlenmemiş ürün olarak satılmaktadır (Anıl ve ark. 2018).

Türkiye fındık üretiminde ve ihracatında dünyada ilk sıradadır. Bu avantajlı konumuyla da dünya findık fiyatlarında belirleyici rol oynamaktadır. Aynı zamanda Türkiye ekonomisine sağladığı döviz girdisiyle de tarım ürünleri arasında findık stratejik bir öneme sahiptir. Ancak Türkiye'nin sahip olduğu dünya findık sektöründeki hâkimiyetinin sürdürebilirliğinin sağlanması için dünya üretimi içerisindeki üretim payını koruması gerekmektedir. Türkiye'nin fındık üretimine yönelik öngörüler sadece ülke içinde merak uyandıran bir durum olmamakla birlikte dünyada da ilgiyle takip edilmektedir. Türkiye'nin dünya findık üretimindeki hâkimiyeti, hem yurt içi hem de yurt dışı fiyatların belirlenmesinde etkin rol oynamaktadır. Bu açıdan, gelecek yıllara yönelik findık üretim miktarlarının tahmin edilmesi, uygun politikalarm belirlenmesi ve üretim planlaması açısından projeksiyon çalışmaları gerekli görülmektedir.

Literatürde bazı tarımsal ürünlerin üretimlerinin tahmin edilmesi için zaman serisi modellerinden faydalanan oldukça fazla çalışma olduğu anlaşılmaktadır. Tarımsal ürünlerde gelecek dönemlere ilişkin tahminlerin yapılmasında zaman serileri ile yapılan birçok ARIMA modellerine rastlanılmıştır. Çelik (2013) findık ve badem üretim miktarlarını tahmin etmek amaciyla, ARIMA tahmin modellerini kullanmıştır. Özer ve İlkdoğan (2013) çalışmalarında dünya pamuk fiyatlarının gelecek dönemlerdeki seyrini Box Jenkins modellerinden ARIMA modeliyle tahmin etmişlerdir. Amin ve ark. (2014) 'Time Series Modeling for Forecasting Wheat Production of Pakistan' başlıklı çalışmalarında, Pakistan'ın 2020, 2030, 2040 ve 2060 yıllarına ait buğday üretimini ARIMA $(1,2,2)$ modeli kullanılarak tahmin etmişlerdir. Özer ve Yavuz (2014) çalışmalarında, Eylül 2005 ve Eylül 2013 dönemi olmak üzere 96 aylık fiyat serilerini kullanarak, findık ihracat fiyatlarının gelecek dönem seyrini ARIMA $(2,1,1)$ modeli ile tahmin etmişlerdir. Uçum (2016), soya üretim ve ticaretinin gelecek beş yıllık dönemini ARIMA modeli ile tahmin etmiştir.

$\mathrm{Bu}$ çalışmanın amacı, 2018-2022 dönemine ilişkin fındık üretim miktarlarının tahmin edilmesidir. $\mathrm{Bu}$ amacı gerçekleştirmek için 1944-2017 dönemlerini içeren fındık üretim verileri kullanılarak, Box Jenkins metodu olan Autoregresif Entegre Hareketli Ortalama Modeli (ARIMA) ile Türkiye'de fındık üretimi tahmin edilmiştir.

\section{MATERYAL ve METOT}

Bir zaman serisi, zaman içinde gözlemlenen bir veri dizisi olarak tanımlanmaktadır. Durağan zaman serilerini modellemenin yaygin olarak kullanılan yöntemlerinden biri (Autoregressive Integrated Moving Average) ARIMA yöntemidir. George Box ve Gwilym Jenkins tarafından geliştirilen bu yaklaşıma Box-Jenkins (BJ) yöntemi de denilmektedir (Uçum, 2016).

ARIMA modelleri tek değişkenli verileri açıklamaya dayalı, zaman serilerinden doğru tahminler yapabilen bir zaman serisi modelidir. ARIMA modelleri oluşturmak için Box-Jenkins metodolojisinin yaklaşımı şu aşamaları içermektedir: (1) Modeli Tanimlama, (2) Parametre Tahmini ve Seçim, (3) Modeli Doğrulama ve (4) Modelin kullanımı (Manoj ve Madhu, 2012).

$\mathrm{Bu}$ çalışmada, zaman serileri analizinde Minitab programı kullanılmıştır. Analizde findık üretim (19442017) verileri TÜİK istatistiklerinden elde edilmiştir. En uygun modele karar vermek için, modellerden elde edilen katsayıların önemlilik testi sonuçlarına bakılıp, tahmin serisi ile orijinal serinin birbirine olan uyumu dikkate alınmıştır. Çalışmada öncelikle incelenen değişkenler için sahip olunan verilerin normal dağılım gösterip göstermediği Kolmogorov Smirnov testi (seriler 30 yıldan fazla olduğu için) ile belirlenmiştir. Fındık üretim serisi normal dağılım gösterdiği için serilere herhangi bir dönüşüm uygulanmamıştır.

\section{BULGULAR ve TARTIŞMA}

Dünyada 2016 yılı itibariyle findık üretiminin gerçekleştirildiği toplam alan 662 bin ha'dır. Dünya fındık üretim alanında Türkiye 437 bin ha ile ilk sirada yer alırken, AB 106 bin ha ile ikinci, Azerbaycan 32 bin ha ile üçüncü ve $\mathrm{ABD}$ ise 15 bin ha ile dördüncü sırada yer almaktadır (Bars, 2017).

Dünyada fındık üretimi 2016 yılında 743 bin ton olarak gerçekleşmiştir. Dünya fındık üretiminin ilk sırasında 420 bin ton ile Türkiye yer alırken, 157 bin ton ile AB ikinci ve 34 bin ton ile Azerbaycan ve ABD üçüncü sırayı paylaşmaktadır. Türkiye dünya fındık üretiminin \%56'sını karşılamaktadır. Dünya fındık üretiminin \%21'ini $\mathrm{AB}$ karşllarken, yaklaşık \%5'ini $\mathrm{ABD}$ ve yine \%5'lik kısminı da Azerbaycan gerçekleştirmektedir (Bars, 2017).

Dünyada fındık ithalatı 2016 yılında yaklaşık 220 bin ton olarak gerçekleşmiştir. Dünya fındık ithalatında Almanya 62 bin ton ile ilk sirada yer alırken, İtalya 44 bin ton ile ikinci, Fransa ise 22 bin ton ile üçüncü sıradadır. Dünya fındık ithalatının \%28'ini Almanya, $\% 20$ 'sini İtalya ve Fransa ise \%10'unu gerçekleştirmiştir (Çizelge 1). 
Çizege 1. Dünya fındık ithalatı (1000 ton)

\begin{tabular}{lrrrrrrr}
\hline Ülkeler & 2010 & 2011 & 2012 & 2013 & 2014 & 2015 & 2016 \\
\hline Almanya & 67.727 & 60.578 & 53.812 & 66.364 & 58.049 & 65.018 & 62.260 \\
İtalya & 31.003 & 32.279 & 26.517 & 35.608 & 36.201 & 40.750 & 43.514 \\
Fransa & 21.130 & 19.738 & 19.990 & 20.311 & 20.486 & 19.868 & 21.821 \\
Kanada & 8.709 & 10.279 & 11.780 & 10.461 & 9.951 & 10.320 & 11.907 \\
İsviçre & 9.460 & 9.512 & 8.751 & 10.300 & 9.684 & 9.026 & 9.360 \\
Rusya & 11.188 & 14.692 & 13.252 & 9.257 & 11.057 & 7.310 & 7.986 \\
Belçika & 9.975 & 11.284 & 11.383 & 12.786 & 10.386 & 12.422 & 6.170 \\
Hollanda & 3.210 & 3.772 & 4.165 & 1.682 & 4.689 & 4.519 & 4.674 \\
İspanya & 5.647 & 4.702 & 4.911 & 5.959 & 4.542 & 3.549 & 3.460 \\
Avustralya & 2.710 & 2.646 & 2.931 & 3.193 & 3.137 & 3.293 & 3.171 \\
Diğer & 118.821 & 51.992 & 52.290 & 64.336 & 47.506 & 40.961 & 45.199 \\
Dünya & 289.580 & 221.472 & 209.782 & 240.256 & 215.689 & 217.036 & 219.521 \\
\hline
\end{tabular}

Kaynak: UN Comtrade, 2018

Dünyada en önemli findık ithalatçısı ülke Almanya'dır. Önemli findık ithalatçılarının Almanya'nın Hamburg kentinde toplanmış bulunması ve aynı zamanda önemli çikolata üreticilerinin Almanya da yer alması fındık ithalatını artırmıştır (Bayramoğlu ve Gündoğmuş, 2017)
Dünyada findık ihracatı 2016 yılında 217 bin ton olarak gerçekleşmiştir. Dünya fındık ihracatında Türkiye 134 bin ton ile ilk sirada yer alırken, Gürcistan 25 bin ton ile ikinci, İtalya ise 24 bin ton ile üçüncü sıradadır. Dünya fındık ihracatının \%62'sini gerçekleştiren Türkiye dünya fındık ihracatında lider konumda yer almaktadır. Gürcistan ise dünya fındık ihracatının \%12'sini gerçekleştirmiştir (Çizelge 2).

Çizelge 2. Dünya findık ihracatı (1000 ton)

\begin{tabular}{lrrrrrrr}
\hline Ülkeler & 2010 & 2011 & 2012 & 2013 & 2014 & 2015 & 2016 \\
\hline Türkiye & 149.604 & 146.322 & 161.462 & 162.932 & 147.096 & 143.158 & 133.755 \\
Gürcistan & 11.294 & 19.093 & 13.609 & 27.730 & 18.942 & 18.385 & 25.337 \\
İtalya & 13.870 & 13.698 & 14.063 & 16.028 & 18.317 & 17.873 & 24.289 \\
Azerbaycan & 8.468 & 12.882 & 10.250 & 10.415 & 11.838 & 245 & 8.299 \\
Şili & 48 & 109 & 107 & 57 & 83 & 1.482 & 6.589 \\
Almanya & 3.669 & 4.869 & 5.245 & 5.213 & 5.900 & 4.789 & 5.898 \\
Hollanda & 1.990 & 2.461 & 3.017 & 2.608 & 3.487 & 3.532 & 3.721 \\
Çek Cumhuriyeti & 592 & 897 & 1.008 & 1.816 & 1.636 & 1.490 & 1.574 \\
İspanya & 2.096 & 2.652 & 2.328 & 2.416 & 2.181 & 1.504 & 1.315 \\
İngiltere & 491 & 496 & 333 & 390 & 474 & 573 & 1.191 \\
Diğer & 6.291 & 5.749 & 6.858 & 9.095 & 9.171 & 8.475 & 5.180 \\
Dünya & 198.413 & 209.227 & 218.280 & 238.701 & 219.125 & 201.506 & 217.149 \\
\hline Kayna & & & & & & &
\end{tabular}

Kaynak: UN Comtrade, 2018

Dünyada findık üreticisi ülke konumunda olmayıp, ihracatçı durumundaki ülkelerin hepsi, Türkiye'den ithal ettikleri fındığı işledikten sonra yeniden ihraç eden ülkelerdir (Erdal ve Uzunöz, 2008). Türkiye'de kültür ırkı fındık yetiştiriciliği ilk olarak Karadeniz Bölgesi'nde başlamış, 1964 yılından sonra findığa alım garantisi verilmesi, bölgeden yapılan göçler gibi sebeplerden ötürü, önce Batı Karadeniz Bölgesi’nin verimli, taban arazilerinde daha sonra ise diğer bölgelere yayılmıştır (Öztürk ve Arıcı, 2017). Türkiye'de Çiftçi Kayıt Sistemi'ne göre 43 ilde findık yetiştiriciliği yapılsa da ticari olarak üretimin tamamına yakını Ordu, Samsun, Giresun, Sakarya, Düzce, Trabzon, Zonguldak, Kocaeli, Artvin, Bartın, Kastamonu, Sinop, Gümüşhane, Rize, Bolu ve Tokat illerinde gerçekleştirilmektedir (TMO, 2017). Ordu ili $\% 31,6$ oranla findık üretiminde ilk sırada yer almaktadır. Aşağıda 2017 yılında Türkiye'de iller bazında fındık üretim oranları verilmiştir (Şekil 1).

Türkiye, dünya fındık üretiminde lider konumda olup, 2016 yılı FAO verilerine göre dünya toplam findık üretiminin \%56'sını karşılamıştır. Türkiye'de 2017 yılında 7 milyon da alanda 675 bin ton findık üretimi gerçekleşmiştir (Bars, 2017).

Fındık, Türkiye ekonomisi için en önemli tarımsal ihracat ürünlerinden birisi olup, Türkiye'den ihraç edilen fındık dünya pazarlarında oldukça rekabetçi bir yapıya sahiptir.

Türkiye 2015/2016 sezonunda 534 bin ton findik ihracatı gerçekleştirmiş olup, bu ihracatın \%78'ini AB ülkelerine yapmıştır. Türkiye'nin bu sezonda gerçekleştirdiği fındık ithalatı ise 9,7 bin ton olup, bu ithalatın da yaklaşık \%80'i AB ülkelerinden yapılmıştır (Çizelge 3). 


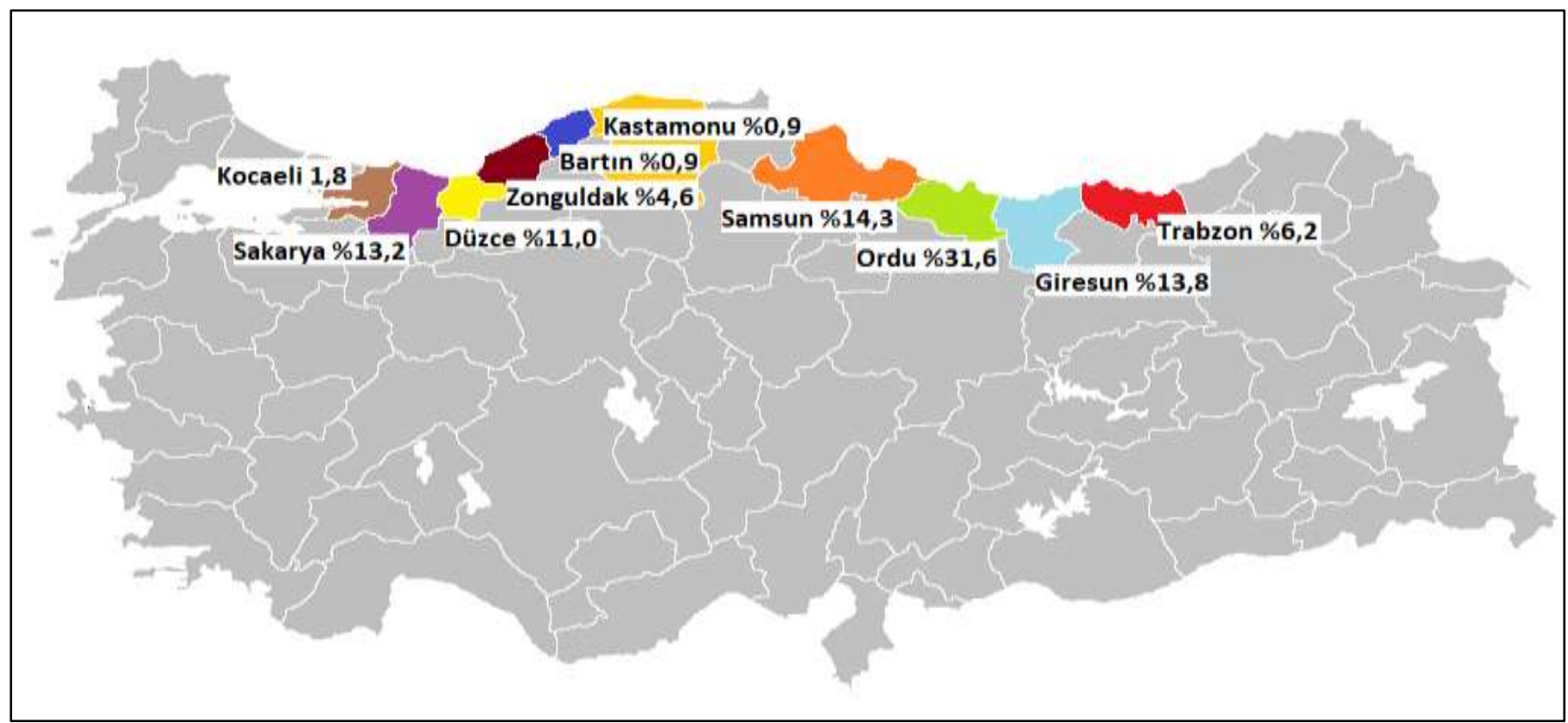

Şekil 1. Türkiye fındık üretiminde önemli olan illerin üretim payları (\%)

Çizelge 3. Türkiye fındık ihracatı ve ithalatı (ton)

\begin{tabular}{lrr}
\hline Piyasa y1lı & İthalat & İhracat \\
\hline $2015 / ' 16$ & 9.710 & 534.274 \\
$2014 / ' 15$ & 7.187 & 492.871 \\
$2013 / ' 14$ & 6.053 & 567.290 \\
$2012 / ' 13$ & 8.697 & 649.211 \\
$2011 / ' 12$ & 3.210 & 411.785 \\
$2010 / ' 11$ & 3.799 & 482.604 \\
\hline
\end{tabular}

Kaynak: TÜIK, 2018

Türkiye 2017 yılında findık (kabuklu) ihracatının ilk sirasında 149 ton ile Irak yer alırken, ikinci surasında 90 ton ile İran ve üçüncü sırasında ise 65 ton ile Lübnan gelmektedir. Fındık (kabuksuz) ihracatında ise 44 bin ton ile İtalya ilk sirada yer alırken, Almanya 21 bin ton ile ikinci ve Fransa ise 14 bin ton ile üçüncü sirada yer almaktadir.

Birçok ekonomik ve finansal zaman serileri, ortalaması durağan olmayan veya bir trend davranışı sergilemektedir. Veriler trend içeriyorsa, bu eğilimin giderilmesi gerekmektedir. ARMA modellerinde de veriler analizden önce durağan forma dönüştürülmelidir. Birim kök testleri, trend verilerinin ilk olarak farklılaştırılması gerekip gerekmediğini belirlemek için kullanılabilir (Anonim, 2018).

ARIMA modeli durağan serilere uygulandığından serilerin durağanlığına bakılmıştır. Bunun için Minitab'da otoregresyon (ACF) ve kismi otoregresyon (PACF) grafikleri ve ilgili istatistik testler yardımıyla durağanlıkları incelenmiştir. Ayrıca Ewievs istatistik programında, serilerin durağanlığ Dickey Fuller testi (ADF) birim kök sınaması ile test edilmiştir. Seri düzey seviyede durağan olmadığından, serinin durağanlaştırılması için fark alma işlemi (2 fark) gerçekleştirilmiştir.

Çizelge 4'de fındık üretim serisine ilişkin 2. fark alındıktan sonra istatistik değerleri görülmektedir. Serinin 2. farkı alındıktan sonra veriler durağan bir yapiya kavuşmuştur.

Çizelge 4. ADF test sonucu

\begin{tabular}{|c|c|c|c|c|c|}
\hline \multirow{2}{*}{ Test } & ADF & \multicolumn{3}{|c|}{ Kritik değerler } & \multirow{2}{*}{ Prob. } \\
\cline { 3 - 5 } & istatistik & $\% 1$ & $\% 5$ & $\% 10$ & \\
\hline 2. & & & & & \\
fark & -8.561 & -4.103 & -3.479 & -3.167 & 0.000 \\
ADF & & & & & \\
\hline
\end{tabular}

Aşağıdaki şekillerde findık üretimi ile ilgili orijinal seriye (Şekil 2) ve serinin ikinci farkının (Şekil 3) alınması ile oluşan seriye ilişkin ACF ve PACF grafikleri gösterilmiştir.Aşağıdaki şekillerde fındık üretimi ile ilgili orijinal seriye (Şekil 2) ve serinin ikinci farkının (Şekil 3) alınması ile oluşan seriye ilişkin ACF ve PACF grafikleri gösterilmiştir.

En uygun modele karar vermek için, modellerdeki katsayıların önemlilik testi sonuçlarına ve tahmin serisi ile orijinal serinin birbirine olan uyumuna bakılmıştır. ARIMA model uygulamasında $(1,2,2)$ uygulaması en uygun model olarak belirlenmiştir. ARIMA $(1,2,2)$ modelinin parametre tahminleri $(\mathrm{t}<0.05)$ anlamlı bulunmuştur (Çizelge 5).

Türkiye'nin fındık üretimine ilişkin 5 ylllık tahmin değerleri Çizelge 6'da gösterilmiştir. Zaman serisi tahmin modellerinden ARIMA yöntemi kullanılarak yapılan analizde en uygun modelin ARIMA $(1,2,2)$ olduğu tespit edilmiştir. 

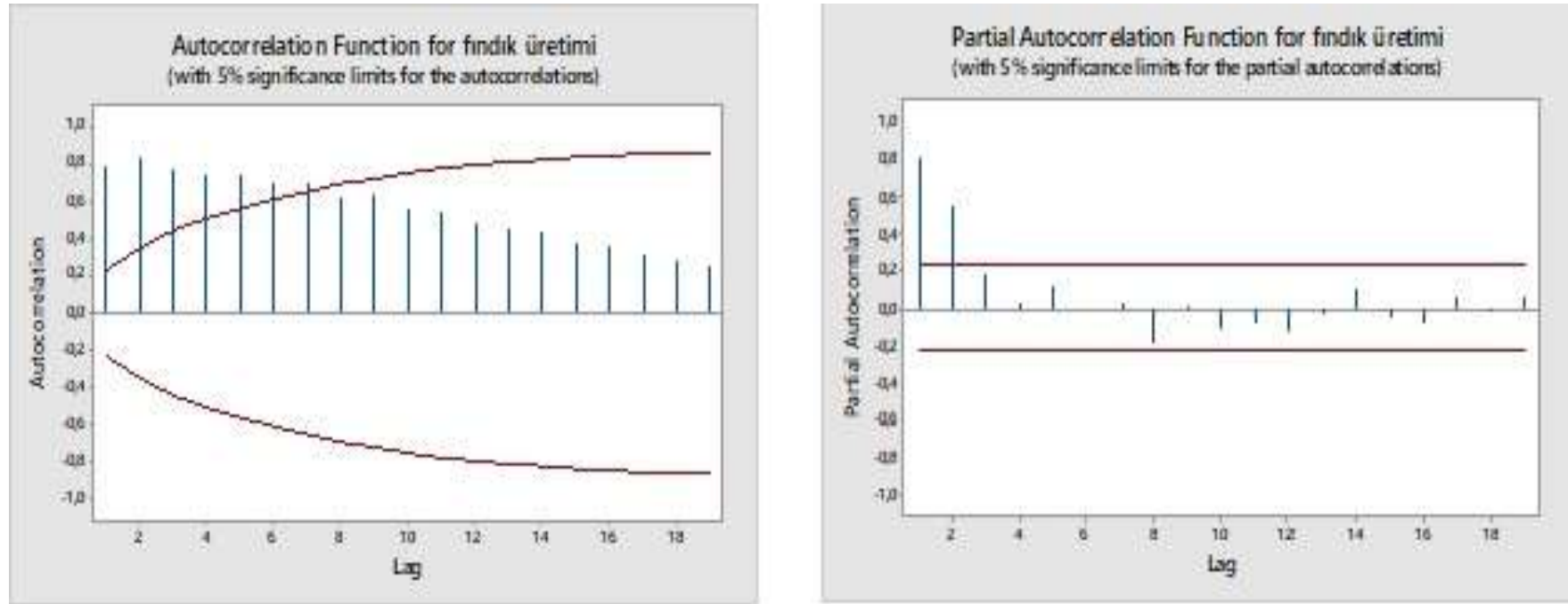

Şekil 2. Fındık üretimine ilişkin otokorelasyon ve kısmi otokorelasyon fonksiyonu
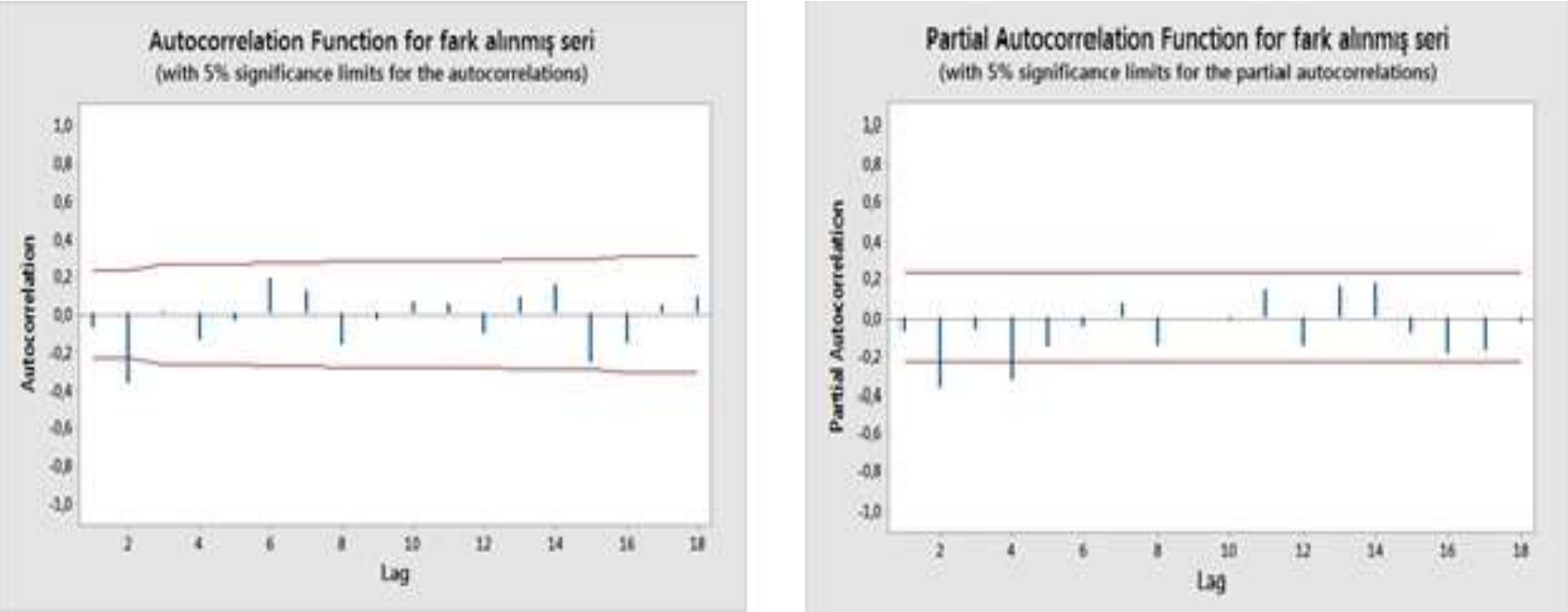

Şekil 3. Fındık üretimine ilişkin ikinci farkı alınmış otokorelasyon ve kısmi otokorelasyon fonksiyon

Çizelge 5. ARIMA $(1,2,2)$ modeli sonucunda findık üretimine ilişkin katsayılar

\begin{tabular}{lcccc}
\hline Model & Katsayı & Standart hata & $\mathrm{t}$ & $\mathrm{p}$ \\
\hline AR 1 & $-0,8842$ & 0,1078 & $-8,20$ & 0,000 \\
MA 2 & 0,8257 & 0,0528 & 15,63 & 0,000 \\
Sabit & $-735,837$ & 6,455 & $-113,99$ & 0,000 \\
\hline
\end{tabular}

Çizelge 6. Findık üretim tahminine ilişkin değerler (ARIMA $(1,2,2))$

\begin{tabular}{cc}
\hline Ylllar & Üretim tahminleri \\
\hline 2018 & 639.394 \\
2019 & 672.973 \\
2020 & 644.644 \\
2021 & 670.317 \\
2022 & 647.506 \\
\hline
\end{tabular}

Modelin uygunluğu tespit edildikten sonra üretim tahmini yapılmıştır. Yapılan tahminlere göre Türkiye'nin 2018 yılında fındık üretimi 2017 yılına göre yaklaşık \%5 oranında azalarak 639.394 tona gerileyeceği tahmin edilmektedir. TÜİK tahminlerine göre 2018 yılında fındık üretim miktarı bir önceki yıla göre \%14,1 oranında azalarak 580 bin ton olacağ 1 tahmin edilmiştir. Çelik (2013) çalışmasında 2018 yılında yaklaşı 627 bin ton findık üretimi öngörmüştür.

Fındık üretiminde 2019 yılında artış görülürken, 2020 yılında tekrar düşüş gösterip 644.644 ton olacağ anlaşılmıştır. Türkiye findık üretimi 2022 yılında ise 647.506 ton olacağı tahmin edilmiştir. Yıllar itibariyle üretim bir yıl artarken, diğer yl azalarak devam edecektir. Bu durum, findıkta görülen periyodisiteden kaynaklanmakta, bir yıl yüksek diğer yıl düşük meyve vermektedir. Bununla birlikte iklim koşulları (don, kuraklık vb.), hastalık (külleme, fındık kurdu) ve zararlılar üretimdeki dalgalanmayı etkilemektedir. Modelin artık değerlerine ilişkin ACF ve PACF grafikleri aşağıda Şekil 4’te verilmiştir. 


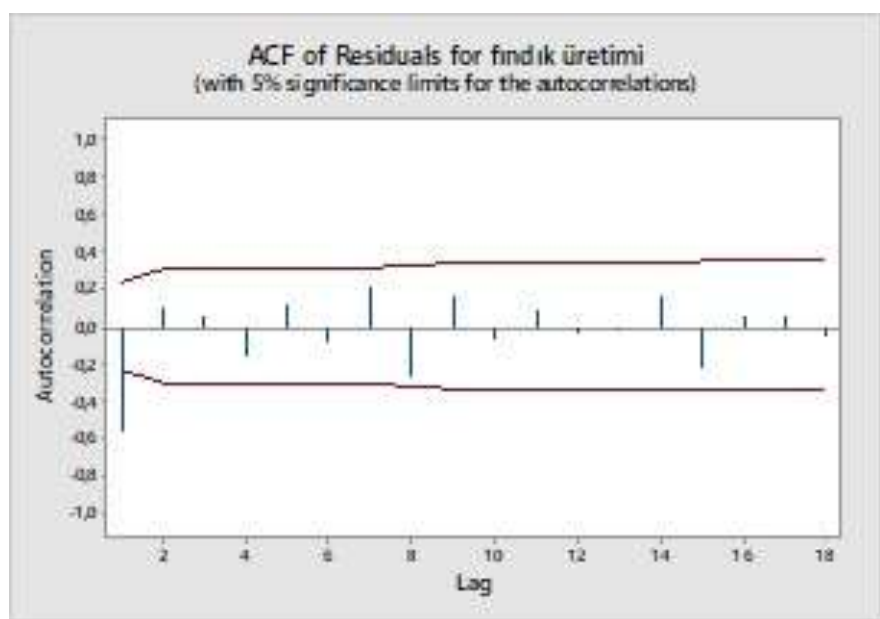

Şekil 4. Modele ait artıkların ACF ve PACF grafikleri

\section{SONUÇ ve ÖNERILER}

Fındık üretimi ve ihracatında küresel pazara hâkim Türkiye, mevcut verilere göre dünya toplam findık üretiminin \%56'sını, findık ihracatının ise \%62'sini karşılamaktadır. Dünyada findık üretiminde Türkiye'yi AB, Azerbaycan ve ABD takip etmektedir.

Türkiye, uluslararası findık piyasanın şekillenmesinde önemli rol oynamaktadır. Türkiye fındık üretimi dünya fındık fiyatlarının oluşumuna etki ederken, aynı zamanda dünya ihracatını da etkilemektedir. Türkiye'de tamamına yakını Karadeniz Bölgesinde yetiştirilen findık, yüzbinlerce ailenin geçim kaynağı olan, katma değer yaratan desteklenmesi gereken önemli bir stratejik üründür. Karadeniz Bölgesinde findık üretim alanları özellikle taban arazilerde daraltılarak üretim devam ettirilmeli, fındık işleme sanayine yönelik teşvikler arttırılmalı ve pazarlama alanları genişletilmelidir. Serbest piyasada oluşacak istikrarlı bir fiyat düzeyiyle ve Türkiye'nin fındık üretim kapasitesi avantajıyla birlikte piyasayı belirleyici konumu sürdürülmelidir.

Bu çalışmada dünya ve Türkiye'de findık piyasalarının mevcut durumu incelenmiş ve Türkiye'nin önümüzdeki 5 yıla ilişkin findık üretim miktarı tahmin edilmiştir. Yapılan analizde en uygun modelin ARIMA $(1,2,2)$ olduğu tespit edilmiş olup, Türkiye fındık üretiminin 2018 yılında yaklaşık 639 bin ton, 2022 yılında ise yaklaşık 648 bin ton olacağı tahmin edilmiştir. Türkiye'de findık üretimi ve üretimin geleceği ile ilgili durum sadece ülke içinde değil dünyada da merak ve ilgiyle takip edilmektedir. Türkiye'nin dünya fındık üretimindeki hâkimiyetini sürdürebilmesi için birim alandan alınan fındık verimi büyük önem arz etmektedir. Türkiye'nin findık verimi dünyada önemli üretici konumundaki ülkelere göre düşüktür. Fındıkta verimi arttırabilmek için, yaşlı ve ekonomik ömrünü tamamlamış findık bahçelerinin sökülerek yenilenmesine yönelik desteklemelerin getirilmesi gerekmektedir. Aynı zamanda findık

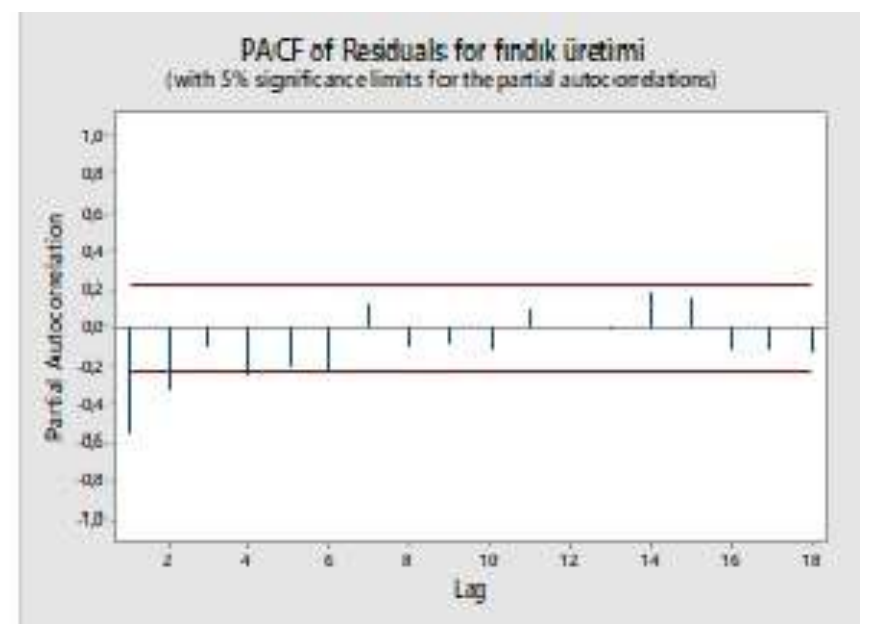

bahçelerinin bakımı büyük önem arz etmektedir. Üreticiler bu konuda bilinçlendirilmeli ve ürüne yönelik teşvikler getirilmelidir. Böylelikle fındıkta üretim artışı alan artırımı olarak değil verim artışıyla gerçekleştirilmelidir.

\section{KAYNAKLAR}

Amin M, Amanullah M, Akbar A 2014. Time Series Modeling For Forecasting Wheat Production of Pakistan. The Journal of Animal \& Plant Sciences, 24(5):1444-1451, ISSN: 1018-7081.

Anıl Ş, Kurt H, Akar A, Bulam Köse Ç 2018. Hazelnut culture in Turkey. XXX. International Horticultural Congress.12-16 August. İstanbul.

Anonim 2018. Unit Root Tests. https://faculty.washington.edu/ezivot /econ584/ notes/unitroot.pdf. (Erişim Tarihi: 10.11.2018).

Bars, T. 2017. Findık Ürün Raporu. TEPGE Yayın No: 298. ISBN: 978-605-2207-05-5.

Bayramoğlu Z, Gündoğmuş E 2007. Dünya Fındık Piyasasının Analizi. Ekonomik Yaklaşım, 18 (65): 71-89.

Çelik Ş 2013. Sert Kabuklu Meyvelerin Üretim Miktarının Box-Jenkins Tekniği ile Modellenmesi. YYÜ Tar Bil Derg (YYU J Agr Scı) 23(1): 18-30.

Erdal G, Uzunöz M 2008. Türkiye ve Avrupa Fındık Fiyatları ve Döviz Kuru Arasındaki Nedensellik İlişkisi. U.Ü. Ziraat Fakültesi Dergisi, 22(2):47-56.

Manoj K, Madhu A 2012. An Application of Time Series Arima Forecasting Model For Predicting Sugarcane Production in India. Studies in Business and Economics, 9(1): 81-94.

Özer OO, İlkdoğan U 2013. Box-Jenkins Modeli Yardımıyla Dünya Pamuk Fiyatının Tahmini. Tekirdağ Ziraat Fakültesi Dergisi. 10(2):13-20

Özer OO, Yavuz GG 2014. Box-Jenkıns Modeli Yardımıyla Fındık Fiyatının Tahmini. XI. Ulusal Tarım Ekonomisi Kongresi 3-5 Eylül. Samsun.

Özkan AH 2012. Türkiye'deki Fındık Üretimi ve Pazarlama Sorunlarına Global Bakış. Çankırı 
Karatekin Üniversitesi Sosyal Bilimler Enstitüsü Dergisi 2(2): 183-192.

Öztürk D, Arıcı YK 2017. Fındık İşletmelerinin Üretim ve Pazarlama Sorunlarının Analizi: Samsun İli Örneği. Ordu Üniversitesi Sosyal Bilimler Araştırmaları Dergisi, 7(1):31-34, ISSN:13099302.

TMO 2016. 2015 Yllı Findık Sektör Raporu. http://www.carsambatb.org.tr/upload/FINDIK\%2 0SEKT\%C3\%96R\%20RAPORU\%202015.pdf (Erişim Tarihi: 10.11.2018).
TMO 2017. 2016 Yllı Findık Sektör Raporu. http://www.tmo.gov.tr/Upload/Document/findikse ktorraporu2016.pdf (Erişim Tarihi: 10.11.2018).

TÜİK 2018. www.tuik.gov.tr. (Erişim Tarihi: 21.02.2018).

Uçum İ 2016. ARIMA Modeli ile Türkiye Soya Üretim ve İthalat Projeksiyonu, TEAD, 2016; 2(1):24-21

UN Comtrade, 2018. https://comtrade.un.org. (Erişim Tarihi: 21.02.2018).

ZMO 2016. http://www.zmo.org.tr. (Erişim Tarihi: 21.02.2018). 